\title{
The impact of acute post-extraction oroantral communications surgical treatment on patients' quality of life in early post-operative period
}

\author{
I. M. Got', I. S. Sorokivskyi, Yu. O. Medvid \\ Danylo Halytsky Lviv National Medical University, Ukraine
}

Key words: oroantral fistula, quality of life, orthodontic space closure

\section{Zaporozhye} medical journal 2017; 19 (6), 804-808

DOI:

10.14739/2310-1210.

2017.6.115262

E-mail:

Ivan.Sorokivsky@

gmail.com
The research objective is to study the impact of plastic surgery different methods of acute post-extraction oroantral communications treatment on patients' quality of life in early post-operative period.

Materials and methods. The study included 41 patient aged between 18 and 58 years receiving treatment of maxillary sinus perforation, which was caused by tooth extraction. The patients were divided into 3 groups - 14, 12 and 15 persons respectively. Plastic surgery of the oroantral communication in the first group was done in accordance with the methods suggested by the authors using collagen cone and membrane. The same surgery in the second group was done with PRF (Platelet-rich fibrin). In the third (control group), the communication was closed by the vestibular flap following the Rehrmann method.

Results of patients' quality of life evaluation after plastic surgery treatment of acute post-extraction oroantral communication show the decrease of its general indicator in early post-operative period in all groups of patients. The general quality of life indicator (well-being indicator) shows a tendency to increase over the first 24 hours after the surgery in both study and control groups. This may mean that a relatively small trauma in a maxillofacial area has a significant influence on patients' perception of their condition and well-being. Absolute numbers of well-being indicator over the first 24 hours after the surgery in the third group were almost 1.5 times higher than those in the groups 1 and 2. In a comparative study of the groups 1 and 3 and then the groups 2 and 3 , we observed a significant difference between well-being indicator levels $(P<0.01)$. The control group demonstrated the return to the pre-operative life quality values on the 7 -th day after the surgery. While at the same time, those values in the study groups were equal to the pre-operative ones already on the 4-th day.

Conclusions. Operation trauma which was caused by the plastic surgery for closure of acute oroantral communication leads to the decrease of patients' quality of life (oral-related conditions), which correlates with the volume of a surgery and its complexity. The use of less traumatic methods of oroantral communication plastics facilitate the statistically significant decrease of these plastics negative impact on patients' quality of life in early post-operative period and enables the earlier recovery.

\section{Киючові слова:} ороантральне сполучення, якість життя, пкастичне закриття.

Запорізький медичний журнал. - 2017. T. 19, № 6(105). C. 804-808

\section{Вплив хірургічного усунення гострих післяекстракційних ороантральних сполучень на якість життя пацієнтів у ранньому післяопераційному періоді}

І. М. Готь, І. С. Сороківський, Ю. О. Медвідь

Мета роботи - встановлення впливу різних методик пластики гострих післяекстракційних ороантральних сполучень на якість життя пацієнтів у ранньому післяопераційному періоді.

Матеріали та методи. До дослідження залучили 41 пацієнта віком від 18 до 58 років, які перебували на амбулаторному лікуванні з приводу перфорацій верхньощелепного синуса, що виникли внаслідок операції видалення зуба. Пацієнтів поділили на 3 групи по 14, 12 та 15 осіб відповідно. У першій групі пластику ороантрального сполучення здійснили запропонованою авторами методикою із використанням колагенових конуса та мембрани. У другій групі пластику виконували із використанням збагаченого тромбоцитами фібрину (PRF). У третій групі, що слугувала групою порівняння, для закриття перфорацій верхньощелепного синуса використали метод Рехмана - трапецієподібним слизовоокісним клаптем.

Результати. Оцінювання змін показників якості життя пацієнтів після пластики гострих післяекстракційних ороантральних сполучень засвідчують погіршення загального показника якості життя в ранньому післяопераційному періоді в усіх групах пацієнтів. Тенденція до збільшення загального показника якості життя в першу добу характерна яку дослідних, такі в контрольній групах. Це свідчить, що операційна травма порівняно невеликого об'єму в щелепно-лицевій ділянці супроводжуються вираженим впливом на суб'єктивне сприйняття свого стану пацієнтами. Абсолютні значення загального показника якості життя на першу добу у третій групі майже в 1,5 раза перевищували аналогічні у 1 та 2 групах. При попарному порівнянні першої із третьою та другої із третьою групами спостерігали значущу різницю між загальними показниками якості життя ( $<<0,01)$. У групі порівняння повернення загального показника якості життя до значень, що спостерігались у передопераційному періоді, відбулось на 7 добу після хірургічного втручання. Водночас у дослідних групах загальний показник якості життя не відрізнявся від доопераційного вже на четверту добу.

Висновки. Операційна травма як наслідок пластичного закриття гострого ороантрального сполучення спричинює погіршення пов'язаної зі стоматологічним здоров'ям якості життя пацієнтів, що корелює з об'ємом хірургічного втручання та його складністю. Використання малотравматичних методик пластики ороантральних сполучень дає можливість статистично значуще зменшити негативний вплив хірургічного втручання на якість життя пацієнтів у ранньому післяопераційному періоді та сприяє швидшому її відновленню.
Ключевые слова: ороантральное сообщение, качество жизни, пластическое закрытие.

\section{Влияние хирургического устранения острых послеэкстракционных ороантральных сообщений на качество жизни пациентов в раннем послеоперационном периоде}

И. М. Готь, И. С. Сорокивский, Ю. О. Медвидь

Цель работы-установление влияния различных методик пластики острых послеэкстракционных ороантральных сообщений на качество жизни пациентов в раннем послеоперационном периоде. 
Материалы и методы. К проведенному исследованию привлекли 41 пациента возрасте от 18 до 58 лет, которые находились на амбулаторном лечении по поводу перфораций верхнечелюстного синуса, возникших в результате операции удаления зуба. Для исследования пациентов разделили на 3 группы по 14, 12 и 15 человек соответственно. В первой группе пластику ороантрального сообщения проводили по предложенной авторами методике с использованием коллагеновых конуса и мембраны. Во второй группе пластику выполняли с использованием обогащенного тромбоцитами фибрина (PRF). B третьей группе, которая служила группой сравнения, для закрытия перфораций верхнечелюстного синуса использован метод Рехмана - трапециевидным слизистонадкостничным лоскутом.

Результаты. Оценки изменения показателей качества жизни пациентов после пластики острых послеэкстракционных ороантральных сообщений свидетельствуют об ухудшении общего показателя качества жизни в раннем послеоперационном периоде во всех группах пациентов. Тенденция к увеличению общего показателя качества жизни в первые сутки характерна как в опытных, так и в контрольной группах. Это свидетельствует о том, что операционная травма сравнительно небольшого объема в челюстно-лицевой области сопровождается выраженным влиянием на субъективное восприятие своего состояния пациентами. Абсолютные значения общего показателя качества жизни в первые сутки в группе 3 почти в 1,5 раза превышали аналогичные в группе 1 и 2. При попарном сравнении первой с третьей и второй с третьей групп наблюдали значимую разницу между общими показателями качества жизни ( $<<0,01)$. В группе сравнения возвращение общего показателя качества жизни до значений, которые наблюдались в предоперационном периоде, произошло на 7 сутки после хирургического вмешательства. В то же время в опытных группах общий показатель качества жизни не отличался от дооперационного уже на четвертые сутки.

Выводы. Операционная травма как следствие пластического закрытия острого ороантрального сообщения вызывает ухудшение связанного со стоматологическим здоровьем качества жизни пациентов, коррелирует с объемом хирургического вмешательства и его сложностью. Использование малотравматичных методик пластики ороантральных сообщений позволяет статистически значимо уменьшить негативное влияние хирургического вмешательства на качество жизни пациентов в раннем послеоперационном периоде и способствует более быстрому его восстановлению.

\section{Actuality}

The acute post-extraction oroantral communication is one of the most common complications which occur in the course of upper molars extraction [10]. Commonly accepted methods of such conditions treatment as a vestibular flap, palatal flap or a Bichat's fat pad etc., involve local tissues, which inevitably leads to additional surgical trauma. Thus, combined with the procedure of a multi-root tooth extraction, they trigger a chain of physiological reactions in local tissues and manifest in pain, edema, limitation of speaking and chewing functions etc. and as a result affect the quality of patients' life [4].

The study of a physical, social and psychological influence of health condition on human's life has been conducted since the middle of $20^{\text {th }}$ century. One of the first instruments for work with patients beyond clinical and laboratory examinations, is Karnofsky Performance Status Scale Index, developed in 1947 for evaluation of cancer patients' quality of life [6]. In 1948, WHO established the definition of health according to which, health is a state of complete physical, mental and social well-being and not merely the absence of disease or infirmity [14], which, in turn, brought up new requirements to the health care system overall and re-directed it from the treatment of illness itself towards the patient treatment as a complex biological unit, who, in addition to the basic morphological and functional characteristics, possesses some individual psychological and social ones.

Nowadays, the patients' quality of life evaluation is gaining more and more importance in the course of effective medical services providing as well as it has established itself as an independent indicator of patients' condition in medical social expertise, prognosis, treatment plans and rehab programs.

The definition of a quality life is projected to the dentistry branch of medicine where it narrows to the notion "Oral health related quality of life", which has been a part of scientific and clinical practices since 1990s [16,18].

Over the recent years there have been developed more than 10 main indexes which can evaluate the impact of oral health on the patients' quality of life [1].
Among the commonly accepted oral health related quality of life evaluation methods, the one that stands out and deserves special attention is OHIP-14 questionnaire.

Oral Health Impact Profile (OHIP) measures individuals' perception of social impact of dental problems on their well-being [17]. A full version of the questionnaire- OHIP-49 consists of 49 questions, which cover seven concept formulated dimensions based on the theoretical model of oral health by Locker [13] and adapted to basic classification of impairments, disabilities and handicaps of WHO [20]. OHIP-14 was developed as a short version for cases where a full set of 49 questions is inappropriate [16].

This tool is widely used in dentistry to estimate the effectiveness of orthopedic rehabilitation of dental patients [3,7], after orthognatic and reconstructive surgeries $[5,15]$ to study new methods of parodontitis treatment [2] etc. However the test sensitivity of this method with regard to the estimation of quality of life in early post-operative period in the alveolar ridge area is of special interest $[4,12]$.

The purpose of our study is to establish the impact of different methods of plastics in the course of acute post-extraction oroantral communication treatment on patients' quality of life in early post-operative period.

\section{Materials and methods}

The study included 41 patient aged between 18 and 58 years, receiving treatment for perforation of maxillary sinus, which was caused by the tooth extraction.

The patients were divided into 3 groups - 14, 12 and 15 persons respectively.

Plastic surgery of the oroantral communication in the first group was done in accordance with the methods suggested by the authors using collagen cone and membrane.

Upon confirmation of oroantral communication, infiltration anesthesia was performed in the area of intervention followed by the revision of the alveolar socket of the extracted tooth. After a very careful deepithelization of marginal gingiva, alveolar socket was filled (without compression) with colla-
Запорожский медицинский журнал. - 2017. T. 19, № 6(105). C. 804-808 
gen cone-shaped bone graft material, which was previously shaped with scalpel.

Collagen membrane was placed on the top of the cone; its perimeter passed beneath the marginal edge of gingiva and was fixed to it by $6-8$ knot stitches. The edges of mucosal tissue of the alveolar ridge were approximated by the mattress stitch. After the procedure, hermetic isolation of the maxillary sinus was checked by direct and reverse control applying moderate force.

In post-operative period the patients were prescribed with anti-bacterial and local antiseptic therapy, as well as painkillers and antiedema medications. The patients were advised to be careful with sneezing with their lips/mouth closed and warned against blowing their noses. Liquid and soft food was recommended for all post-operative period. Stitches were removed in 10-12 days; a control check up of hermetic isolation was performed.

The same surgery in the second group was done with PRF (Platelet-rich fibrin).

To make PRF, patient's blood from the median cubital vein was collected with the help of vacuum blood collecting systems (4-6 tubes $/ 9 \mathrm{ml}$ each). Then this blood was centrifuged for 12 minutes at a speed of $2400 \mathrm{rpm}$. After PRF extraction, using special instruments, a special plug for socket filling and membrane were formed.

Anesthesia, revision of the socket and preparation of the gingival edge was done in accordance with the same procedure as in the group 1.

The PRF plug was put into the void of communication then it was sutured and fixed to the mucosal tissue of gingiva On the top of the plug, the autogenous membrane was fixed, approximating the edges of mucosal tissue with stitches. Local and general therapy for the post-operative period was the same as in the group 1 . Stitches were removed on the 10-12 day.

In the third (control group), the communication was closed by the vestibular flap following the Rehrmann method.

Infiltration anesthesia was performed in the area of intervention. Two linear incisions were made on the vestibular surface of the alveolar ridge form medial and distal edges of the communication to the transitional fold. Two incisions were made in the way so that they created the sides of trapeze, where the bigger base is directed towards the transitional fold and the smaller base is actually a vestibular edge of the oroantral communication.

With the help of the raspator, mucosal periosteal flap was carefully elevated. Then the bone edges of the alveolar socket were examined. Pointed and sharp edges were reduced and

Table 1. WBI of the patients in pre-operative period (points), $\mathrm{M} \pm \mathrm{m}$

\begin{tabular}{llll}
\hline & Group 1 & Group 2 & Group 3 \\
\hline Before the surgery & $4.14 \pm 0.51$ & $4.00 \pm 0.54$ & $3.93 \pm 0.50$ \\
1 day & $23.36 \pm 0.80^{* * *}$ & $24.42 \pm 0.69^{* *}$ & $36.67 \pm 1.27^{* * *}$ \\
2 day & $14.07 \pm 0.53^{* * *}$ & $13.58 \pm 0.63^{* *}$ & $29.73 \pm 1.38^{\star * *}$ \\
3 day & $9.00 \pm 0.53^{* * *}$ & $9.08 \pm 0.54^{* *}$ & $23.13 \pm 1.08^{* *}$ \\
4 day & $4.21 \pm 0.58$ & $3.25 \pm 0.39$ & $14.87 \pm 1.16^{* * *}$ \\
5 day & $3.00 \pm 0.43^{* *}$ & $2.83 \pm 0.32^{*}$ & $9.40 \pm 0.67^{* * *}$ \\
6 day & $2.64 \pm 0.44^{* *}$ & $2.58 \pm 0.36^{*}$ & $6.13 \pm 0.66^{* *}$ \\
7 day & $2.64 \pm 0.44^{* *}$ & $2.58 \pm 0.36^{*}$ & $4.07 \pm 0.62$ \\
8 day & $2.57 \pm 0.47^{* *}$ & $2.58 \pm 0.36^{*}$ & $3.13 \pm 0.57^{*}$ \\
9 day & $2.57 \pm 0.47^{* *}$ & $2.58 \pm 0.36^{*}$ & $2.73 \pm 0.49^{* *}$ \\
10 day & $2.57 \pm 0.47^{* *}$ & $2.58 \pm 0.36^{*}$ & $2.67 \pm 0.49^{* *}$ \\
\hline
\end{tabular}

Significance of the difference between the numbers before and on the certain day after the surgery: $*: P<0.05 ; * *: P<0.01 ; * * *: P<0.001$ smoothened. Mucosal periosteal flap was mobilized crossing the periosteum from inside, horizontally. Free edge of the mucosal periosteal flap and palatal mucosa, which surrounded the socket were deepithelized. Then the careful revision and hemostasis were performed. Mucosal periosteal flap was tightly fixed to the edges of the wound by knot stitches. Upon closure, hermetic isolation was checked with the help of nasal-oral test.

Post-operative recommendations, local and general therapy, removal of stitches procedures were similar to those in other clinical groups.

The evaluation of dental status of the patients and its influence on their quality of life were conducted by the standardized questionnaire OHIP-14, which was translated and adapted into Ukrainian in accordance with the currently accepted methodology recommendations $[8,9,11,19]$.

The answers for the suggested questions were interpreted in the form of points which stood for: 0 - never, 1 - hardly ever, 2 - occasionally, 3 - quite often, 4 - fairly often. The results were imported to the table and were statistically processed.

Taken advantage of the features, which characterized the chosen method, we could interpret the findings as a quantitative expression of the oral health as a component of a general well-being of the patient. It was calculated by summing up all points - all the answers per every single day - from 0 to 56 .

That is, the bigger was the sum of points, the more significant was the negative impact of oral health on patients' quality of life. In this way we detected the degree to which the surgical intervention affected patient' life and it's tendencies in the post-operative period.

The data was statistically processed by the Statistica 8.0 software. We counted the mean values (M) and their standard errors $(m)$. The statistical significance of the numbers before and on the certain day after the surgery was estimated by Wilcoxon signed-rank test. The difference (p) between the mean values (in points) for both groups before the surgery and on the 1-10 days after it was estimated by the Mann-Whitney $U$ test.

\section{Results of the well-being indicators evaluation}

In the first group (plastics with the collagen cone and membrane) on the first day after the surgery, the patients expressed a significant deterioration of a well-being indicator (WBI) (23.36 \pm 0.80 points) compared to that before the surgery (4.14 \pm 0.51 points) (Table 1). Statistically significant difference between the numbers $(P<0.001)$ had been persisting during the first, second and third days after the surgery. On the fourth day WBI was $4.21 \pm 0.58$ and it was not significantly different from the pre-operation condition and showed a steady decrease until the $8^{\text {th }}$ day $(2.57 \pm 0.47)$.

In the second group (plastics with PRF plug and membrane), we also observed a rapid deterioration of WBI in comparison with the pre-operative period $(24.42 \pm 0.69$ and $4.00 \pm 0.54$ respectively, $\mathrm{P}<0.001$ ).

This figure had been constantly improving until reaching $3.25 \pm 0.39$ points on the fourth day, which was not significantly different from the initial level $(P>0.05)$.

In the third (control) group, WBI in general showed a rapid increase at the beginning of the post-operative period, in particular the data for the first day after the surgery was 
$36.67 \pm 1.27$ points compared to that before the surgery $3.93 \pm 0.50$. Statistically significant deterioration of WBI $(P<0.001$ and $P<0.01)$ was observed until the $6^{\text {th }}$ day. For the $7^{\text {th }}$ day this indicator was $4.07 \pm 0.62$ points and was not significantly different from that before the operation $(P>0.05)$.

After comparing the WBI data in patients from all groups (Table 2), we did not find any significant difference in pre-operative period $(P>0.05)$. While in paired comparison study, where the findings for the first and the second groups were contrasted to those of the control group (group 3), the data showed a significant difference $(P<0.001)$, which had been persisting until the $6^{\text {th }}$ day. While at the same time, in comparative study of the first and second groups, the difference in values obtained during the whole period of study was found invalid $(P>0.05)$.

It is also worth mentioning that in the patients of the first and second study groups, WBI returned to its initial points on the $4^{\text {th }}$ day after the surgery, while in those from the 3 rd (control) group - only on the $7^{\text {th }}$ day (Fig. 1).

\section{Discussion}

The results of WBI changes after the plastics of acute post-extraction oroantral communication indicate a significant deterioration $(P<0.01)$ of patients' quality of life in early post-operative period in all groups in this study. Tendency to increase of WBI points on first day was observed in all groups (study and control) $(36.67 \pm 1.27,23.36 \pm 0.80$ and $24.42 \pm 0.69$ points on the $1^{\text {st }}, 2^{\text {nd }}$ and $3^{\text {rd }}$ groups compared to $4.14 \pm 0.51,4.00 \pm 0.54$ and $3.93 \pm 0.50$ points before the surgery, $P<0.001)$. These finding are relevant to other studies, done on surgical interventions in the alveolar ridge area of jaws [12]. This may mean that a relatively small trauma in maxillofacial area is characterized by the significant impact on the subjective perception of their condition from the patients' perspective.

Mean values of WBI during the first day in the third group (36.67 \pm 1.27 points) were almost 1.5 times higher than those of groups 1 and $2(23.36 \pm 0.80$ and $24.42 \pm 0.69$ points respectively, $\mathrm{P}<0.001$ (Fig. 2a). In paired comparison study between the first and third, and the second and the third groups, we observed a statistically significant difference in WBI $(p<0.01)$. In our opinion, it is due to the fact that plastics of oroantral communication done by the Rehrmann method, which was performed on the patients of the control group, involve some additional incisions to form a trapeze-shape flap and further mobilization by a horizontal cross of the periosteum in the trapeze base. Such procedure causes the release of inflammatory mediators, which is a natural reaction of tissues to the surgical trauma. Histamine, serotonin, bradykinin and prostaglandins, which are released in the area of intervention, cause post-operative pain and edema. These, in turn, are the main triggers of deterioration of patients' quality of life [4]. Also, surgical method which was applied to the patients of the $3^{\text {rd }}$ group, involved crown displacement of a mucosal periosteal flap, which caused a considerable reduction in the depth of oral vestibule and, as a result, cheek mobility. This led to a considerable limitation of movements during eating and speaking.

According to the findings, obtained in this study, we can assume the surgical methods, which minimize the trauma and alterations in oral vestibule, lead to the decrease of a

Table 2. Statistical significance of the difference in WBI values in clinical groups (p)

\begin{tabular}{llll}
\hline Difference between groups: & 1 vs 2 & 1 vs 3 & 2 vs 3 \\
\hline Before the surgery & $>0.05$ & $>0.05$ & $>0.05$ \\
$1-6$ days & $>0.05$ & $<0.001$ & $<0.001$ \\
$7-10$ days & $>0.05$ & $>0.05$ & $>0.05$ \\
\hline
\end{tabular}

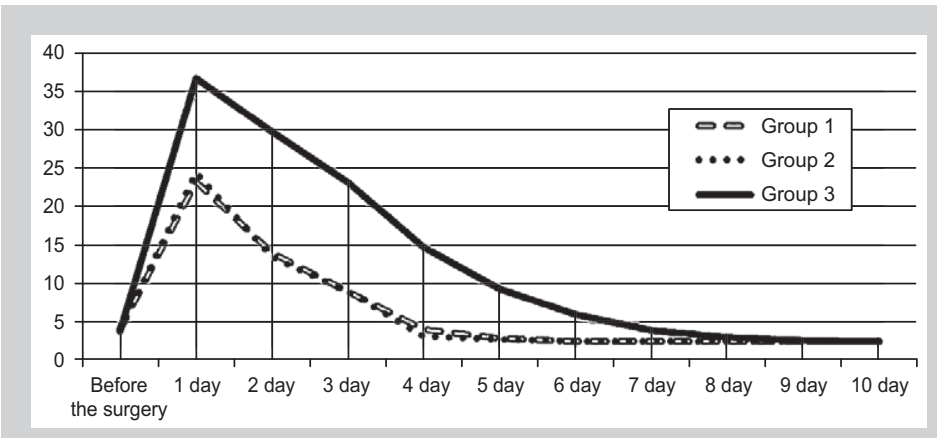

Fig. 1. Well-being indicator during the post-operative period (points).

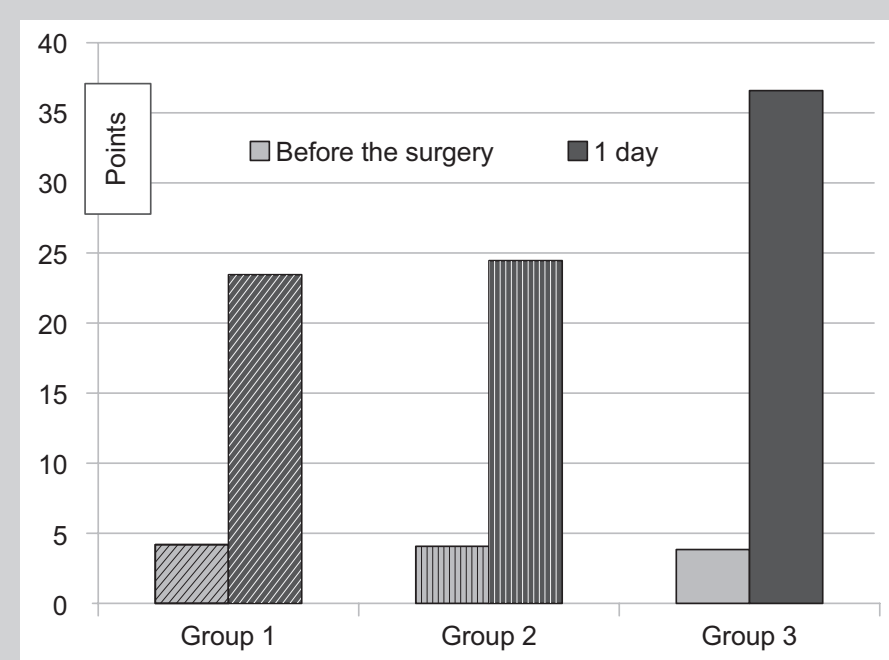

Fig. 2a. Change in patients' life quality on the first day after the surgical intervention.

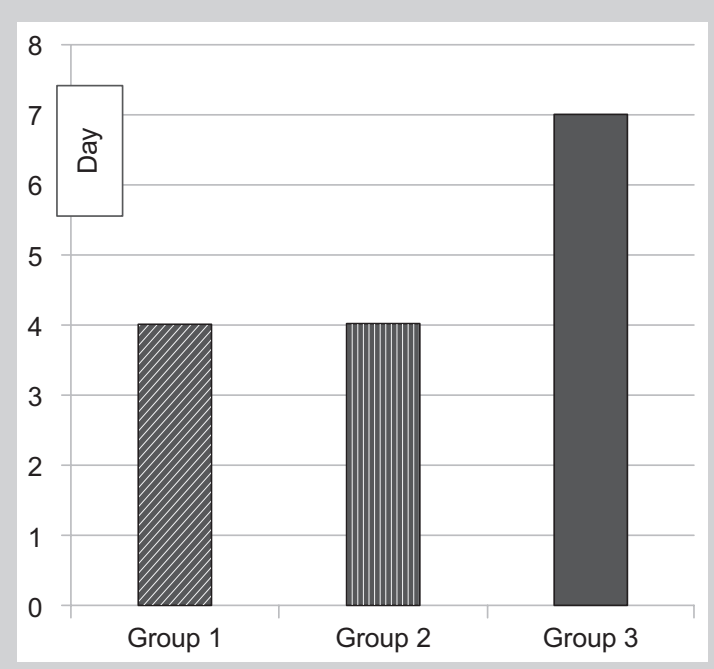

Fig. 2b. Period of return to the pre-operative level of WBI 
post-operative discomfort for patients and functional lesions already on the first day following the surgical intervention.

In control group, return to pre-operative level of WBI was observed on the $7^{\text {th }}$ day after the surgical intervention ( $4.07 \pm 0.62$ points as opposed to $3.93 \pm 0.50$ points before the surgery). While at the same time, in study groups the WBI was not significantly statistically different from the pre-operative level already on the $4^{\text {th }}$ day $(P>0.05)$ (Fig. $\left.2 b\right)$. Fast recovery of quality of life related to oral health in patients who underwent plastic surgeries of oroantral communications using less invasive methods, may be an indicator of the fact, that psycho-emotional sphere of human nature, as well as individual's social and physical activity, are closely connected to the recovery of physiological status of maxillofacial area.

\section{Conclusions}

1. Surgical trauma which occurred in the course of plastic closure of acute oroantral communication leads to deterioration of patients' quality of life in terms of their oral health.

2. The level of WBI increase and period of its recovery correlates with the volume of surgical intervention and its complexity.

3. Less invasive methods of oroantral communication plastics enable a statistically significant reduction of negative impact caused by surgical intervention on patients' quality of life in early post-operative period and facilitate its fast recovery.

Perspectives for further studies. The results of given study indicate a perspective implementation and improvement of new methods of acute oroantral communications plastics, which may have less considerable influence on patients' quality of life. The study of suggested methods of plastic potential results and their impact on morphology and function of soft and hard tissues of alveolar ridge make the base for the potential further scientific research.

\section{References}

[1] Gazhva, S. I., Guluev, R. S., \& Gazhva, Yu. V. (2012) Kachestvo zhizni paciientov s zabolevaniyami polosti rta (obzor literatury) [The quality of life in paitents with diseases of oral cavity (review of literature)]. Sovremennye problemy nauki i obrazovaniya, 4, [in Russian].

[2] Dmitrieva, E. O. (2014) Eksperymentalne obgruntuvannia zastosuvannia materialu Easy-graft ta dynamika yakosti zhyttia pislia yoho vykorystannia u khvorykh na heneralizovanyi parodontyt II stupenia [Rationale fo experimental using of Easy-Graft material and dynamics of life quality after its applying in patients with generalized periodontitis II severity level]. Morpholohiia, 8(1), 40-45. [in Ukrainian].

[3] Alzarea, B. K. (2016). Assessment and Evaluation of Quality of Life (OHRQoL) of Patients with Dental Implants Using the Oral Health Impact Profile (OHIP-14)-A Clinical Study. Journal of clinical and diagnostic research, 10(4), ZC57-60. doi: 10.7860/JCDR/2016/18575.7622.

[4] Deepti, C., Rehan, H. S., \& Mehra, P. (2009). Changes in quality of life after surgical removal of impacted mandibular third molar teeth. Journal of maxiIlofacial and oral surgery, 8(3), 257-260. doi: 10.1007/s12663-009-0063-2.

[5] Dholam, K. P., Dugad, J. A., \& Sadashiva, K. M. (2017). Impact of oral rehabilitation on patients with head and neck cancer: A study using the Liverpool Oral Rehabilitation Questionnaire and the Oral Health Impact Profile-14. The Journal of prosthetic dentistry, 117(4), 559-562. doi: 10.1016/j.prosdent.2016.06.019.

[6] Fayers, P. M., \& Machin, D. (2013). Quality of life: the assessment, analysis and interpretation of patient-reported outcomes. John Wiley \& Sons.

[7] Nicolaisen, M. H., Bahrami, G., Schropp, L., \& Isidor, F. (2016). Functional and Esthetic Comparison of Metal-Ceramic and All-Ceramic Posterio Three-Unit Fixed Dental Prostheses. The International journal of prosthodontics, 29(5), 473-81. doi: 10.11607/ijp.4646.

[8] Beaton, D. E., Bombardier, C., Guillemin, F., \& Ferraz, M. B. (2000). Guidelines for the process of cross-cultural adaptation of self-report measures. Spine, 25(24), 3186-3191. doi: 10.1097/00007632-200012150-00014.

[9] Guillemin, F., Bombardier, C., \& Beaton, D. (1993). Cross-cultural adaptation of health-related quality of life measures: literature review and proposed guidelines. Journal of clinical epidemiology, 46(12), 1417-1432. doi: 10.1016/0895-4356(93)90142-N
[10] Batra, H., Jindal, G. \& Kaur S. (2010). Evaluation of different treatment modalities for closure of oro-antral communications and formulation of a rational approach. Journal of maxillofacial and oral surgery, 9(1), 13-18. doi: 10.1007/s12663-010-0006-y.

[11] Herdman, M., Fox-Rushby, J., \& Badia, X. (1997). ‘Equivalence'and the translation and adaptation of health-related quality of life questionnaires. Quality of Life Research, 6(3), 237-47. doi: 10.1023/A:1026410721664.

[12] Ibikunle, A. A. \& Adeyemo, W. L. (2016). Oral health-related quality of life following third molar surgery with or without application of ice pack therapy. Oral and maxillofacial surgery, 20(3), 239-247.

[13] Locker, D. (1988). Measuring oral health: a conceptual framework. Community Dent Health, 5, 3-18.

[14] World Health Organization (1948). Preamble to the Constitution of the World Health Organization, as adopted by the International Health Conference, New York, pp. 19-22 (June 1946); signed on 22 July 1946 by the Representatives of 61 States,(Official Records of the World Health Organization, No. 2 p. 100) and Enterd into Force on 7 April 1948. Retrieved from http://www. who. int/abouwho/en/definition. html.

[15] Silva, I., Cardemil, C., Kashani, H., Bazargani, F., Tarnow, P., Rasmusson, L., \& Suska, F. (2016). Quality of life in patients undergoing orthognathic surgery-A two-centered Swedish study. Journal of Cranio-Maxillofacial Surgery, 44(8), 973-978. doi: 10.1016/j.jcms.2016.04.005.

[16] Slade, G. D. (1997). Derivation and validation of a short-form oral health impact profile. Community dentistry and oral epidemiology, 25(4), 284-290. doi: 10.1111/j.1600-0528.1997.tb00941.x.

[17] Slade, G. D., \& Spencer, A. J. (1994). Development and evaluation of the Oral Health Impact Profile. Community dental health, 11(1), 3-11.

[18] Slade, G. D. (1997). Measuring oral health and quality of life. Chapel Hill.

[19] Papagiannopoulou, V., Oulis, C. J., Papaioannou, W., Antonogeorgos, G., \& Yfantopoulos, J. (2012). Validation of a Greek version of the oral health impact profile (OHIP-14) for use among adults. Health and quality of life outcomes, 10, 7. doi: 10.1186/1477-7525-10-7.

[20] World Health Organization (1980). International classification of impairments, disabilities, and handicaps: a manual of classification relating to the consequences of disease; publ. for trial purposes in accordance with resolution WHA29. 35 for the Twenty-ninth World Health Assembly, May 1976. Geneva.

\section{Information about authors:}

Got' I. M., MD, PhD, Professor, Department of Surgical Dentistry and Maxillofacial Surgery, Danylo Halytsky Lviv National Medical University, Lviv, Ukraine.

Sorokivskyi I. S., MD, Assistant, Department of Surgical Dentistry and Maxillofacial Surgery, Danylo Halytsky Lviv National Medical University, Lviv, Ukraine.

Medvid Yu. O., MD, PhD, Associate Professor, Department of Surgical Dentistry and Maxillofacial Surgery, Danylo Halytsky Lviv National Medical University, Lviv, Ukraine.

\section{Відомості про авторів:}

Готь І. М., канА. меА. наук, професор каф. хірургічної стоматології та щелепно-лицевої хірургії, Аьвівський національний меАичний університет імені Аанила Галицького, Україна.

Сороківський І. С., асистент каф. хірургічної стоматології та щелепно-лицевої хірургії, Аьвівський національний меАичний університет імені Аанила Галицького, Україна.

Медвідь Ю. О., канд. меА. наук, доцент каф. хірургічної стоматології та щелепно-лицевої хірургії, ^ьвівський національний медичний університет імені Аанила Галицького, Україна.

\section{Сведения об авторах:}

Готь И. М., канА. меА. наук, профессор каф. хирургической стоматологии и челюстно-лицевой хирургии, Аьвовский национальный медицинский университет имени Аанияа Гамицкого, Украина.

Сорокивский И. С., ассистент каф. хирургической стоматологии и челюстно-лицевой хирургии, Аьвовский национальный медицинский университет имени Аанила Галицкого, Украина. МеАвиАь Ю. О., канА. меА. наук, Аоцент каф. хирургической стоматологии и челюстно-лицевой хирургии, Аьвовский национальный медицинский университет имени Аанила Галицкого, Украина.

Конфлікт інтересів: віАсутній.

Conflicts of Interest: authors have no conflict of interest to declare.

Надійшло Ао редакції / Received: 07.06.2017

Після Аоопрацювання / Revised: 12.06.2017

Прийнято Ао Аруку / Accepted: 04.09.2017 